\title{
Analysis of automation in manufacturing processes, inventory control and sales in micro, small and medium-sized companies of Acámbaro, Gto.
}

\section{Análisis de automatización en procesos de fabricación, control de inventarios y ventas en micro, pequeñas y medianas empresas de Acámbaro, Gto.}

\author{
BARRERA-FIGUEROA, Mayra Verónica†*, RODRÍGUEZ-RODRÍGUEZ, Graciela and UGALDE- \\ ZAMUDIO Giovanni
}

Universidad Tecnológica de León, campus Acámbaro, México.

ID $1^{\mathrm{er}}$ Autor: Mayra Verónica, Barrera-Figueroa / ORC ID: 0000-0002-3079-2470

ID $1^{\mathrm{er}}$ Co-author: Graciela, Rodríguez-Rodríguez.

ID $2^{\text {nd }}$ Co-author: Giovanni, Ugalde-Zamudio

DOI: $10.35429 / J I O .2020 .7 .4 .1 .11$

Received July 10, 2020; Accepted December 30, 2020

\begin{abstract}
The development of products destined to cover specific needs plays an important role when it is possible to have feedback, in terms of functionality, on the part of the final user for the consolidation of the product. Seeking such consolidation and identifying opportunities for improvement, in this paper a redesign was made based on specific criteria to align the manufacturing to mass production. The following premises were raised: 1) validation of the de-sign proposal; 2) comparative and operational analysis; 3) geometry optimization for weight and production cost reduction. This paper proposes a new design of the drawbar body of a tractor (case study) and the theoretical framework is established taking the bases of the concurrent engineering to define and characterize the final architecture configuration. Is reported the methodology used for the development of this research and the results obtained by finite element analysis for architecture optimization. Finally, are presented the defined strategies for aligning manufacturing to production.
\end{abstract}

\section{Resumen}

The objectives of this work are decisive to obtain an upto-date and reliable status regarding the use of automation in micro, small and medium-sized enterprises (MPYMES), and thus to seek a direct relationship in terms of the use of automated elements either in the production process, inventories and / or sales; in addition to how this can influence your competitiveness. The method used was the statistician, from a finite universe sample. The approach to the analysis of research results was quantitative with a descriptive scope, by which it was possible to examine how much of Acámbaro's MYPIMES, Gto. make use of automation in the aforementioned processes. The sample is obtained from the city of Acámbaro, Gto., selected place as a case study. With the results obtained, it helps to determine various factors that impact the chosen control sector; a certain part makes use of automation in some of the areas of interest, others mention ignoring the terms, and others show great interest in optimizing your business. Based on the information, various improvement recommendations are made.

Company, Automation, Process

Redesign, Characterization, Optimization

Citation: BARRERA-FIGUEROA, Mayra Verónica, RODRÍGUEZ-RODRÍGUEZ, Graciela and UGALDE-ZAMUDIO Giovanni. Analysis of automation in manufacturing processes, inventory control and sales in micro, small and medium-sized companies of Acámbaro, Gto. RINOE Journal-Industrial Organization. 2020. 4-7:1-11.

*Correspondence to Author (Email: mbarrera@utleon.edu.mx)

$\dagger$ Researcher contributing first author. 


\section{Introduction}

It is a reality that the use of current technology can be a fundamental part of the performance of any activity, even more so, in an environment as competitive as the productive sector; technology should be considered as indispensable and not as optional. By implementing current technology, and focusing on the automation section, it is possible to optimize the activities carried out, which leads to an increase in the effectiveness and efficiency of the procedures.

To obtain reliable information on the use and impact of automation in micro, small and medium-sized enterprises (MPYMES), an analysis is carried out in the city of Acámbaro, Gto., Which is characterized by having a large commercial sector in this category. Based on the fact that both the manufacturing processes, inventory control and product marketing should not implement obsolete methodologies, it is necessary to know how the three mentioned areas are currently, and if the commercial activity in the area has been adapted to the new technological circumstances in which it is immersed.

It is considered that the use and knowledge of automation is a priority to ensure the good positioning of any company, so it seeks to determine the status of automation implemented by micro, small and medium-sized companies.

The information in this article is approached in such a way that it is part of the description of the methodology implemented for the research, subsequently the data analysis is carried out, and based on them, the results obtained are determined; as well as deductions and improvement considerations.

\section{Method description}

The development of this research was based on a statistical method, using a finite universe sample in the town of Acámbaro, Gto. applied in micro, small and medium enterprises; under a confidence level of $95 \%$, with a margin of error of the sample of $5 \%$.
The focus of the analysis of the research results was quantitative with a descriptive scope, to identify characteristics of the Acambarense population with the relationship to the aforementioned, it was based on the contribution of Namakforoosh (2005), who said that the research is used descriptive "to calculate the portion in a specific population that have certain characteristics" (p. 91), because the city of Acámbaro was considered, under the aforementioned variables, in addition to describing the status of micro, small and medium enterprises of this city, in relation to automation in manufacturing processes, in inventory control and in the sales process.

For data collection, a survey was used as an instrument because it is carried out on all interviewees with the same questions, in the same order, and in a similar social situation (Vidal Díaz, 2001, p. 13), it was applied face to face with the interviewees, which consisted of 18 questioners, with specific items focused on responding to the research questions posed. The research was based on the scientific method, which according to Castán (2014) is a systematic research process that consists of interdependent parts. The stages that make up the scientific method are: 1) definition of the problem, 2) formulation of hypotheses (deductive reasoning), 3) collection and analysis of data, 4) confirmation or rejection of hypotheses, 5) results, 6) conclusions (p. 5).

\section{Methodology to be developed}

\section{Theoretical framework}

The city of Acámbaro, was founded on September 19, 1526, is located in the Southeast region of the state of Guanajuato, has a territorial extension of 877.43 square kilometers, which represents $2.85 \%$ of the total surface of the state (Encyclopedia of municipalities and delegations of Mexico, nd), speaking of economic entities in Acámbaro there are 5,694 of these, of which 5,669 are micro and small companies.

INEGI (2009) mentions that micro, small and medium-sized enterprises (MPYMES) have great importance in the economy and in employment at the national and regional level, both in industrialized countries and in those with less development. 
MPYMES companies represent the segment of the economy that contributes the largest number of economic units and employed personnel worldwide; hence the relevance of this type of companies and the need to strengthen their performance by having a fundamental impact on the global behavior of economies.

Speaking specifically, the microenterprise is the smallest productive unit of the business structure, in terms of the scale of fixed assets, sales and number of employees, that carries out production, trade or service activities in rural or urban areas [...] it is a productive selfemployment unit with no more than 10 employees, whereas a small company employs between 11 and 50 people; and a medium-sized company employs between 51 and 100 people (Lizarazo Beltrán, 2009, p. 15), in the same way Ramírez (2006) mentions that the SME is defined as "any unit of economic exploitation, carried out by natural or legal persons, in business, agricultural, industrial, commercial or service activities, either in rural or urban areas; It also adds that the medium-sized company has a plant of workers between 51 and 200 people, while the small company has between 11 and 50 workers (p. 10-13).

Now, addressing the term automation that "is the action by which activities carried out by an operator, in a production process, are transferred or transferred to a machine, which is governed by equipment that can be wired or programmed electronic" (Solbes i Mozó, 2014, p. 13), likewise Iborra, Dasí, Dolz and Ferrer (2014) say that automation is the result of the incorporation of information technologies into manufacturing (p. 336); On the other hand, in the article entitled Manufacturing and organization, they cite the Strategic Plan of the National Program for Industrial Technological Development and Quality, 2000-2010, which addresses that automation is considered as the management of information in companies for decision-making in real time, incorporates computer science and automated control for the autonomous and optimal execution of processes designed according to engineering criteria and in line with the plans of the business management (Cordoba Nieto, 2006), instead Palomares and Mertens (1991) state that automation is "a phenomenon that involves the work process itself and the market.
It is not only a process of transformation of human work, by substituting man for machine, but also the appearance of new needs in society, which are reflected in market demand.

There are different levels of automation according to García (2005), these can be analyzed depending on the level it produces: a) Level 1. Elementary, b) Level 2. Simple machines, d) Level 3. Process, c) Integrated management level (p. 23); Sánchez and Pizarro (2010) state that there are four levels: Level 1. Manual operation, Level 2. Semi-automatic, Level 3. Automatic, Level 4. Computerized. On the other hand, automating also brings with it a series of advantages, on the website Grup MCR (2016), they mention some, among them are that optimal levels of quality are achieved, cost savings, production time, personnel safety, improvement of data flow, competitive advantage, however, they also mention disadvantages and this is that specialized personnel are required, on the other hand for Mungaray and Lagarda (1990), the new type of industrial technology although it replaces skilled and specialized workers, creates in turn, new types of training and jobs such as programmers, security guards, operators and regulators, this being an advantage (p. 85).

Parallel to the above, Katz and Calatayud (2019) mention that automation and robotization facilitate the implementation of decisions without the need for human intervention, this brings benefits which are huge gains in time, agility and risk management between the elements key to the supply chain [...] The application of the technologies of the fourth industrial revolution, can be called "supply chain 4.0 , this is characterized by a high level of interconnection between the physical and digital fields (page 13), combined to the above, Sánchez (2008), contributes that an integrated program relates the functions of product development, manufacturing supply and planning within the company, the resulting process must be a network of activities that must be managed simultaneously (p. 101).

Speaking of the commercial area, there are three large areas or contact channels susceptible to automation according to García (2001), these are: Customer service, marketing processes and automation of the sales force ( $\mathrm{p}$. 130). 
Sales force automation (connecting salespeople to headquarters from remote computing connections) is perhaps the main force behind changing sales organizations today, it has freed salespeople from daily visits, and that results in more time with clients (Sánchez Gómez, 2008, p. 118).

\section{Problem Statement}

Companies increasingly seek to optimize resources and increase their productivity, in many aspects within themselves, such as in the production process, in the way they control supplies and in the way of marketing their products and / or services, everything in favor of increasing efficiency and improving delivery times; For the aforementioned, the question arises of knowing how the small and mediumsized companies of Acámbaro, Gto., are in the automation of manufacturing processes as well as identifying difficulties that are faced in it; in the same way, to know the state in which they are in the automation processes in the inventory control and automation in the sales area processes.

\section{Research questions}

In order to give an order to what we wanted to analyze, the following research questions were formulated:

- How do companies in Acámbaro, Gto., Consider what their automation is in general?

What level of automation do the companies in Acámbaro, Gto have?

What are the main problems identified by the Acámbaro, Gto companies regarding the manufacturing process of the product and / or service?

Do the companies in Acámbaro, Gto., Have an automation process to control supplies?

Do the companies in Acámbaro, Gto., Have an automation process in the sales area?

Do the companies in Acámbaro, Gto., Make use of any tool to automate their sales process?
What recommendations do the companies of Acámbaro, Gto., Provide to achieve global automation in their businesses?

\section{Objecives}

Analyze how the companies of Acámbaro, Gto, consider their automation to be in general.

Identify the level of automation that companies in Acámbaro, Gto.

Know what the main problems are identified by the companies Acámbaro, Gto regarding the manufacturing process of the product and / or service.

Determine if the companies in Acámbaro, Gto., Have an automation process to control supplies.

Establish whether the companies in Acámbaro, Gto., Have an automation process in the sales area.

Define if the companies of Acámbaro, Gto., Make use of any tool to automate their sales process.

Describe the recommendations provided by companies in Acámbaro, Gto., To achieve global automation in their businesses

\section{Hypothesis}

- Ho. The companies of Acámbaro, Gto., Are considered with an automation in general of Manual Manufacturing.

H1. The companies of Acámbaro, Gto., Are not considered with a general automation of Manual Manufacturing.

- Ho. The companies in Acámbaro, Gto., Are in a level 1 of automation: turn-onoff devices, sensors, alerts, alarms.

H1: The companies of Acámbaro, Gto., Are not in a level 1 of automation: Turnon-off devices, sensors, alerts, alarms. 
- Ho. The lack of automation, technology and training; are the main problems identified by the companies of Acámbaro, Gto. in the manufacturing process of the products and / or services.

H1. The lack of automation, technology and training; They are not the main problems identified by the companies of Acámbaro, Gto. in the manufacturing process of the products and / or services.

- Ho. The companies in Acámbaro, Gto. Do have an automation process to control supplies.

H1. The companies in Acámbaro, Gto., Do not have an automation process to control supplies.

- Ho. The companies of Acámbaro, Gto., Do have an automation process in the sales process.

H1. The companies in Acámbaro, Gto., Do not have an automation process in the sales process.

- Ho. The companies of Acámbaro, Gto., Do use a tool to automate their sales process.

H1. The companies in Acámbaro, Gto., Do not use any tool to automate their sales process.

- Ho. Make purchases with certified suppliers, carry out a plant distribution analysis and invest in technology, is what the companies of Acámbaro, Gto recommend.

H1. Making purchases with certified suppliers, carrying out a plant distribution analysis and investing in technology, is not what the companies of Acámbaro, Gto recommend.

\section{Research justification}

It is convenient to carry out the research because the data that this yields can be for the use of the same companies surveyed and thus, have a broader vision of how they can improve, in addition to being new information that is helpful to the general population; consequently, it will have a social relevance with the city of Acámbaro, Gto., so that future businesses implement automation processes, since this can have many benefits as mentioned by García (2005) who says that the advantages of automation are: producing a constant quantity, supplying necessary quantities at the precise moment, increasing productivity and increasing job security (p. 21).

This research has theoretical value, because it will be possible to know the behavior of the automation processes in the production process, in the supply control process and in the commercial or sales process, of the companies in the area.

\section{Analysis of quantitative results with a descriptive scope}

The analysis of the results was carried out through the Design of Survey Analysis program (DYANE, 2005), in which a database was integrated, which was able to produce graphs expressing basic descriptive statistics.

\section{Analysis results}

- How they categorize their companies in a general way, referring to automation:

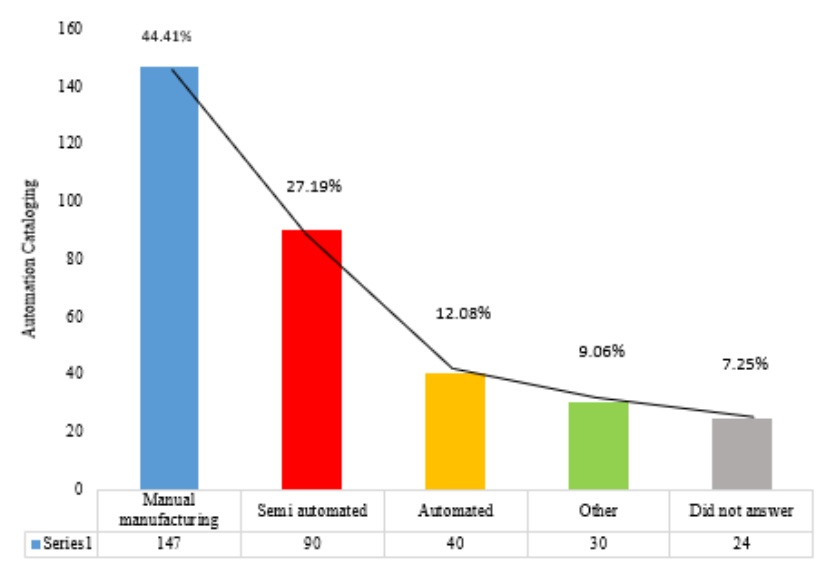

Graphic 1 Automation in general Source: Own source 
In Graphic 1, it can be seen that $44.41 \%$ of the population of micro, small and medium companies classify their organization as manual manufacturing, on the other hand $27.19 \%$ consider it as semi automated, on the other hand $12.08 \%$ think they are automated Likewise, 9.06\% said another option, these were where they mentioned that it was artisanal, commercial, services and even that it does not apply; finally, $7.25 \%$ abstained from issuing a response.

- How do companies in Acámbaro, Gto consider the level of automation:

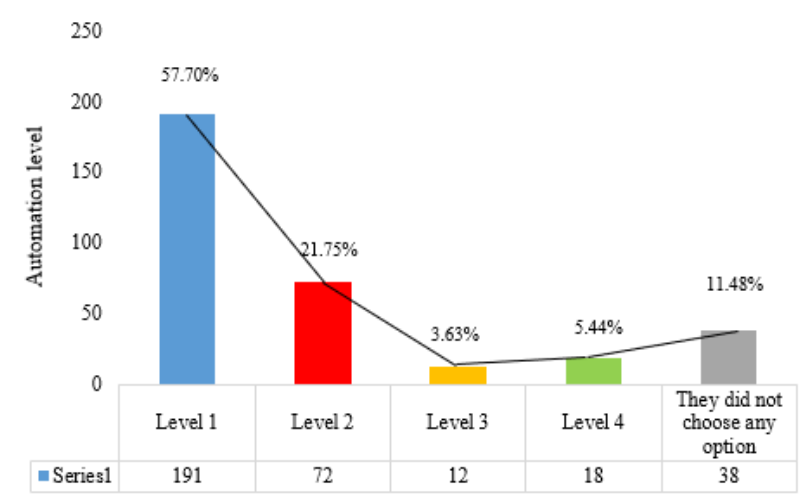

Graphic 2 Automation level

Source: Own source

To carry out Graphic 2, options were provided to the micro, small and medium enterprises of Acámbaro, Gto; The options that were given to the respondents were considered, these were:

a) Level 1: Turn-on-off devices, sensors, alerts, alarms.

b) Level 2: Automation, Human-Machine Interface (interaction), SCADA (Supervision, Control and Data acquisition), Programmable Controllers, digital systems packages.

c) Level 3: Energy control systems, Active controllers, Immediate responses, IT operators.

d) Level 4: Smart company (intelligent), selfadjustable, adaptable according to different conditions, use of cutting-edge technology (connectivity, information management, use of virtual and / or augmented reality), digitization, business processes and drivers in line.
Once the options are contextualized, it can be seen that $57.50 \%$ of the companies consider they are at level 1 (Turn-on-off devices, sensors, alerts, alarms), on the other hand it is observed that $11.48 \%$ did not choose any option However, $21.75 \%$ mention they are at level 2 (Automation, Human-Machine Interface (interaction), SCADA (Supervision, Control and Data acquisition), Programmable Controllers, digital systems packages); Likewise, 5.44\% say they are at level 4 (Smart Company (intelligent), self-adjustable, adaptable according to different conditions, use of cutting-edge technology (connectivity, information management, use of virtual and / or augmented reality), digitization, business processes and online drivers); Finally $3.63 \%$ say they have a level 3 (Energy control systems, Active controllers, Immediate responses, IT operators).

- Problems identified by the companies Acámbaro, Gto regarding the manufacturing process of the product and / or service:

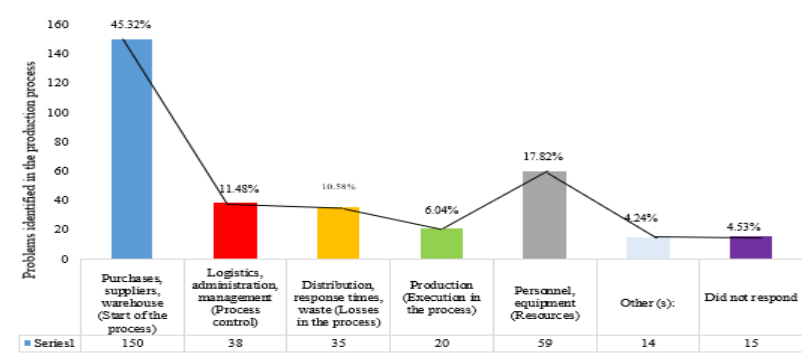

Graphic 3 Problems identified in the production process Source: Own source

In Graphic 3 it can be observed that $45.32 \%$ of the micro, small and medium companies of Acámbaro, Gto; they present problems in the purchasing, supplier and warehouse area, that is to say at the beginning of the process; On the other hand, $17.82 \%$ have faults with their personnel and equipment, specifically with human and technical resources; In addition to the above, $11.48 \%$ mentioned that their problems are in the area of logistics, administration and management, that is, in the control of the process; On the other hand, $10.58 \%$ expressed having difficulties in distribution, response times, waste, which means that there are losses in the process; However, $6.04 \%$ mentioned that the problem is in the production area, emphasizing the execution of the process; It is worth mentioning that $4.53 \%$ abstained from answering; Finally, $4.24 \%$ selected the other option, where they mentioned a delay with customers, a decline in the markets and simply stated that they had no problem. 
- What are the problems identified above?

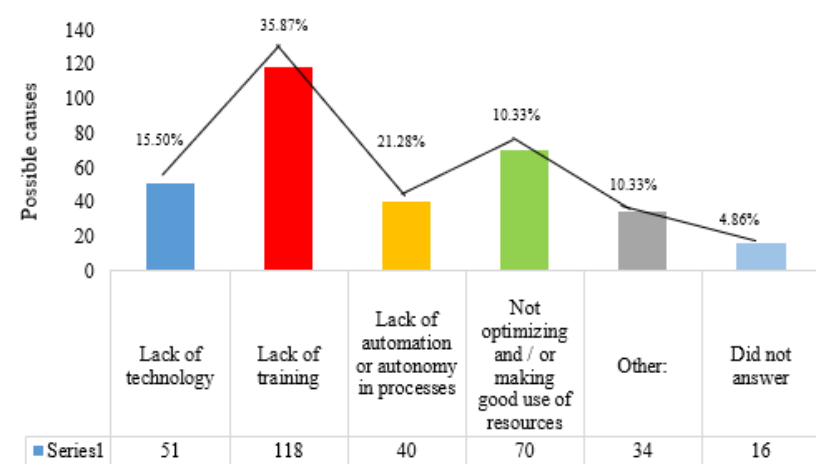

Graphic 4 Possible causes of problems identified in the process productive

Source: Own source

In Graphic 4, the causes of the problems identified in graphic 3 are shown, where $35.87 \%$ of the micro, small and medium-sized enterprises of Acámbaro, Gto; state that the possible causes of the problems identified are the lack of training for staff, on the other hand $21.28 \%$ said that the causes are due to the lack of automation or autonomy in the processes, however $15.50 \%$ of the companies mentioned that the problems are due to the lack of technology, on the other hand $10.33 \%$ said that it was due to not optimizing resources well and / or making good use of them; finally with $4.86 \%$ the companies that did not respond are shown.

- Automation process in the control of supplies of the companies of Acámbaro, Gto:

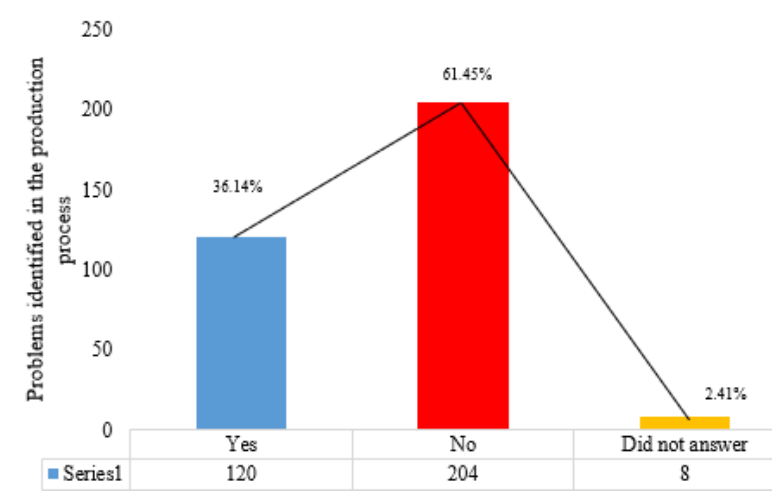

Graphic 5 Problems identified in the production process Source: Own source

To the businessmen of the Acámbaro, Gto sample; They were asked if they had an automated process for the control of supplies, therefore in graph 5 it is shown that $61.45 \%$ expressed not having an automated process for that area, likewise $36.14 \%$ said they did have an automated process for control of supplies; finally $2.41 \%$ did not provide an answer.
- Automation process in the sales area of the companies of Acámbaro, Gto:

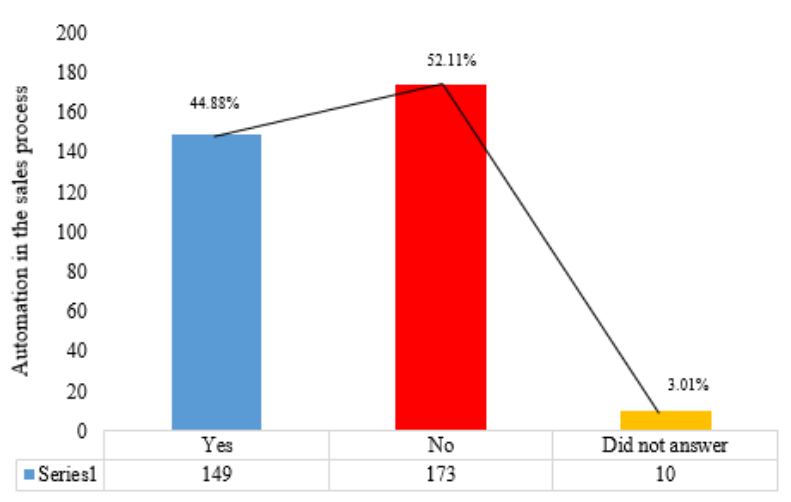

Graphic 6 Automation in the sales process Source: Own source

In Graphic 6 the results are shown focused on whether in the companies of Acámbaro, Gto; They have automation processes in the sales area, where $52.11 \%$ said they did not have, on the other hand $44.88 \%$ mentioned whether to have a process, finally 3.01 did not respond.

- Support tool to automate the sales process of companies in Acámbaro, Gto:

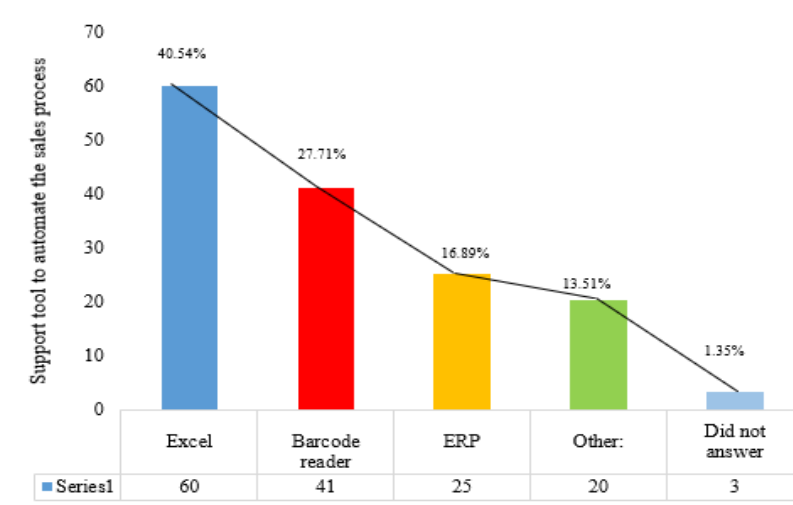

Graphic 7 Support tool to automate the sales process Source: Own source

Graphic 7 shows the results of the opinion of $44.88 \%$ of the micro, small and medium enterprises of Acámbaro, Gto; who said yes to have an automation process, who were questioned which tool they used to automate their processes, where, with $40.54 \%$ mentioned that they use the Excel tool, instead $27.71 \%$ said they use a barcode reader On the other hand, $16.89 \%$ said they use the ERP system, likewise $13.51 \%$ said another, in which Sicar, Point of Sale System, Aspel, Private system, Smartphone classification of clients, Atenea, real estate CRM, Ciber Planet System stand out, SAP system, cash register. Finally, $1.25 \%$ is appreciated, which represents the companies that did not respond.

BARRERA-FIGUEROA, Mayra Verónica, RODRÍGUEZRODRÍGUEZ, Graciela and UGALDE-ZAMUDIO Giovanni. Analysis of automation in manufacturing processes, inventory control and sales in micro, small and medium-sized companies of Acámbaro, Gto. RINOE Journal-Industrial Organization. 2020 
- Recommendations of the companies of Acámbaro, Gto., To achieve global automation in their businesses:

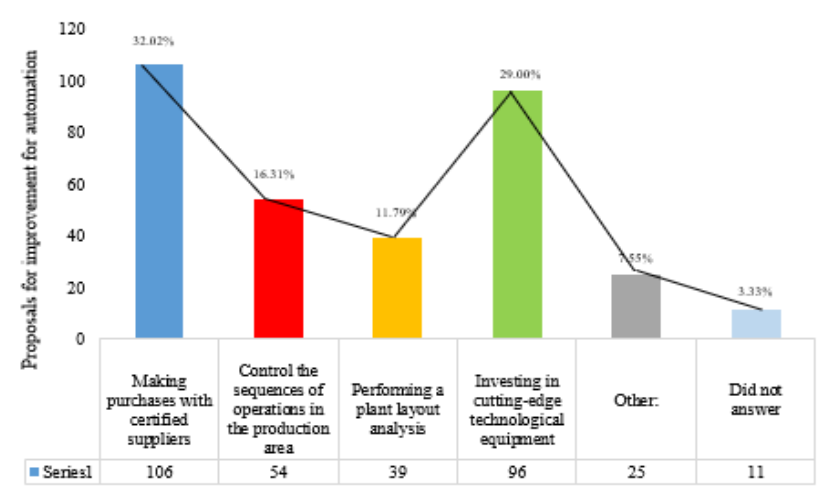

Graphic 8 Proposals for improvement for automation Source: Own source

In Graphic 8 it can be seen that $32.02 \%$ of the micro, small and medium enterprises of Acámbaro, Gto; They state that they can improve for automation by making purchases with qualified suppliers, however $29.00 \%$ think that they can improve by investing in cuttingedge technological equipment; on the other hand, $16.31 \%$ propose that they can improve by controlling the sequences of operations in the production area; Likewise, $11.79 \%$ express that they can improve if they carry out a plant distribution analysis; Similarly, $7.55 \%$ mentioned other options, these were that they must renew and modernize the business, constant and improved training, work on the responsibility of their positions, control the sales sequence, have new products, optimize times, not have suppliers Unique, you are not interested in having an automated company, having someone to control supplies, acquire new machines, seek government support, systematizing processes. Finally, 3.33\% of the companies that did not answer the question are shown.

\section{Analysis of the Hypotheses}

An analysis of the hypotheses formulated at the beginning of the investigation is carried out, where the verification of them is shown below, based on the results:

- Ho. The companies of Acámbaro, Gto., Are considered with an automation in general of Manual Manufacturing.

H1. The companies of Acámbaro, Gto., Are not considered with an automation in general of Manual Manufacturing.
Based on the above, the null hypothesis is accepted, with a trend greater than $44.41 \%$, the population of micro, small and medium-sized companies, classify their organization as manual manufacturing.

- Ho. The companies of Acámbaro, Gto., Are in a level 1 of automation: Turn-on-off devices, sensors, alerts, alarms.

H1: The companies of Acámbaro, Gto., Are not in a level 1 of automation: Turn-on-off devices, sensors, alerts, alarms.

Based on the above, the null hypothesis is accepted; since $57.50 \%$ of the surveyed companies consider they are in level 1 of automation (turn-on-off devices, sensors, alerts, alarms).

- Ho. The lack of automation, technology and training; are the main problems identified by the companies of Acámbaro, Gto. in the manufacturing process of products and / or services.

H1. The lack of automation, technology and training; they are not the main problems identified by the companies of Acámbaro, Gto. in the manufacturing process of products and / or services.

The null hypothesis is accepted because the companies mention having problems with technology and especially with training; since $35.87 \%$ of the micro, small and medium enterprises of Acámbaro, Gto .; state that the possible causes of the problems identified are the lack of staff training.

- Ho. The companies in Acámbaro, Gto., Do have an automation process to control supplies.

H1. The companies in Acámbaro, Gto., Do not have an automation process for controlling supplies.

According to the above, the alternative hypothesis is accepted, because $61.45 \%$ of the micro, small and medium-sized companies of the mentioned city expressed not having an automated process for the supply control process.

- Ho. The companies in Acámbaro, Gto., Do have an automation process in the sales process. 
H1. The companies in Acámbaro, Gto., Do not have an automation process in the sales process.

Now, from the previous hypotheses, the alternative hypothesis is accepted because $61.45 \%$ of the micro, small and medium-sized companies in the mentioned city expressed not having an automated process for the sales process.

- Ho. The companies of Acámbaro, Gto., Do use a tool to automate their sales process.

H1. The companies of Acámbaro, Gto., Do not use any tool to automate their sales process.

Continuing with the hypothesis testing, from those shown above, the null hypothesis is accepted because of $44.88 \%$ of the companies in Acámbaro, Gto :; They said yes to have a tool for the sales process represented with $40.54 \%$ say they use the Excel tool to automate their sales process, this being the biggest trend.

- Ho. Make purchases with certified suppliers, carry out a plant distribution analysis and invest in technology, is what the companies of Acámbaro, Gto.

H1. Making purchases with certified suppliers, conducting a plant distribution analysis and investing in technology, is not what the companies of Acámbaro, Gto recommend.

Finally, the last hypotheses raised are analyzed, where the null hypothesis is accepted, this derived from the results where a trend greater than $32.02 \%$ is obtained, which expresses that companies think that they can improve their automation by making purchases with qualified suppliers, in addition to the $7.55 \%$ that the study showed, mention was made of certain recommendations, such as the need to renew and modernize the business, constant and improved training, work on the responsibility of their positions, control the sales sequence, have new products, optimizing times, not having unique suppliers, they are not interested in having an automated company, having someone to control supplies, acquire new machines, seek government support and systematize processes.

\section{Acknowledgments}

A special thanks to the Technological University of León, an institution that constantly supports the generation of research and technological developments, which meet defined needs, as well as always considering a favorable impact on educational programs.

We thank managers and all personnel involved in various committees related to investigation, since unconditional support and good will are essential to achieve the objectives that are set.

We express great gratitude to the micro, small and medium-sized companies in the city of Acámbaro, Gto., Which kindly agreed to participate in the research; for responding to all the questions raised, for sharing information and for opening its doors to maintain a relationship and commitment with the education sector.

Last but not least, we thank the Research department of the UTL, for being aware of various related activities and for their constant attention to the adequate monitoring of each of them.

\section{Conclusions}

It was relevant to discover that most companies classify their businesses as manual manufacturing, therefore, their priority is not that their processes be automated; In addition, more than half of the surveyed population are at level 1, where they only have turn-on-off devices, sensors, alerts, alarms; which means that they still do not have the technology to consider their businesses Smart.

On the other hand, since companies with manual manufacturing are in a greater tendency, they consider they lack training, in order to avoid problems that affect money.

Likewise, the companies of Acámbaro, Gto., Do not consider it relevant to have an automated process for the control of supplies, upon detecting through research that the highest percentage does not have an automated process for this function; followed by a smaller percentage amount, but quite a weight of those that do consider it important to have a process of this type for the control of raw materials, merchandise and inventories in general. 
Parallel to the above, it was relevant that the micro, small and medium enterprises of Acámbaro, Gto; they still do not consider it important to automate their businesses, some are due to lack of knowledge of the term, in other cases, companies are traditionalists and show reluctance to change. On the other hand, in relation to automating the sales process, it was found that they do not have something to support it, however, of the percentage that said yes to do so, they showed that they do it through various softwares, to facilitate the process; An important finding was that a minimum percentage, located in the "other" answers, mentioned that they rely on a CRM, which according to its acronym in English Costumer Relatioship Management, is a business strategy that implies a change in the business model focused on the automated management of all points of contact with the client, whose objective is to attract, retain and make the client profitable by offering the same face through the centralized analysis of their data (García, 2001, p. 26).

Finally, it is concluded that the surveyed companies are not totally open to automation, as it highlights what was detected through the recommendations they make to achieve better automation, that they have no interest in having an automated company, having someone to take charge to keep control of supplies, acquire new machines, seek government support, systematizing processes; which serves to investigate in the future if it is because they do not know the benefits of automation in a process of this nature or it is because it does not adhere to their needs.

\section{References}

Cordoba Nieto, E. (2006). Manufatura y Organización. Redalyc, 120-128. Retrieved on 2020 November 25, from: https://www.redalyc.org/articulo.oa?id=643/64 326315.

Enciclopedia de los municipios y delegaciones de México. (s.f.). inafed.gob.mx. Retrieved on November 25, 2020, from: http://www.inafed.gob.mx/work/enciclopedia/E MM11guanajuato/municipios/11002a.html.

Castán, Y. (2014). Introducción al Método Científico y sus Etapas. Retrieved on November 27, 2020, from: http://www.haykhuyay.com/A1/Generic/ECO1/ U1U2/metodoCientifico.pdf
García Varcárcel, I. (2001). CRM. Gestión de la Relación con Los Clientes. Madrid: Fundación Confemetal.

Grup MCR. (July 29, 2016). MCR. Retrieved on November 25, 2020, from: https://www.mcr.es/ventajas-y-desventajas-dela-automatizacion-industrial/

Iborra, M., Dasí, Á., Dolz, C., \& Ferrer, C. (2014). Fundamentos de dirección de empresas. Conceptos y habilidades directivas. España: Ediciones paraninfo.

INEGI. (2009). inegi.org.mx. Retrieved on November 25, 2020, from: https://www.inegi.org.mx/contenidos/programa s/ce/2009/doc/minimonografias/m_pymes.pdf

INEGI. (2015). INEGI. Retrieved on November 25, 2020, de existen 5694 de éstas, de las cuales 5669 son mypes (INEGI, 2015).

Katz, R., \& Calatayud, A. (2019). Cadena de suministro 4.0: Mejores prácticas internacionales y hoja de ruta para América Latina. Estados Unidos: Banco Interamericano de Desarrollo.

Lizarazo Beltrán, M. (2009). Jóvenes emprendedores: Comprometidos con el Desarrollo Sostenible de los territorios rurales. Ecuador: Instituto Americano de Cooperación para la Agrícultura.

Mungaray Lagarda, A. (1990). Crisis, automatización y maquiladoras. México: Universidad Autónoma de Baja California.

Palomares, L., \& Mertens, L. (1991). Empresa y trabajador ante la automatización programable. México: Migueol Ángel Porrua.

Ramírez Castro, M. M. (2006). Tendencias espaciales de la pequeña y mediana empresa en Bogotá 1990-2000. Colombia: Universidad Nacional de Colombia, sede Bogota.

Sánchez Gómez, G. (2008). Cuantificación y generación de valor en la cadena de suministro extendida. León: Del blanco Editores. 
Sánchez, V., \& Pizarro, D. (2010). Diagnóstico del nivel de automatización en las pequeñas y medianas industrias de la Cuenca. Ingenius. Revista de ciencia y tecnología, 1-13. Retrieved on November 25, 2020, from: https://dialnet.unirioja.es/descarga/articulo/597 2774.pdf.

Santesmases, M. (2005). DYANE Versión 4. Madrid: Pirámide.

Solbes i Mozó, R. (2014). Manual de Automatismos Industriales. Conceptos y procedimientos. España: Nau Libres. 